\title{
Творческая среда, как вариант организационной структуры внеурочной и урочной деятельности.
}

Нестеренко Лариса Валерьевна, учитель английского языка, высшей квалификационной категории, МБОУ Одинџовской СОШ № 8.

Аннотация: Управление развитием детской одарённости в условиях школы - это регулирование системы работы с одарёнными школьниками. Иностранный язык как одно из средств общения и познания окружающего мира занимает особое место в системе современного образования в силу своих социальных, познавательных и развивающих функций. Время, в котором мы живем, выдвинуло перед общеобразовательной школой задачу воспитания свободной, творческой, образованной, культурной, разносторонней и активной личности. Изучение иностранного языка требует от учеников усердия и кропотливой работы. Учителю иностранного языка необходимо помнить, что эффект его уроков во многом зависит от того, как полученные знания и умения могут быть использованы ими в жизни. Развитие творческих способностей личности на уроках иностранного языка могут осуществляться лишь в творческой деятельности в процессе обучения.

Управление развитием детской одарённости в условиях школы - это регулирование системы работы с одарёнными школьниками в целях получения желаемого результата в их обучении, воспитании и развитии. Одаренность - это результат природных задатков и социальной среды: игровой, учебной, трудовой, в которой проявляется деятельность ребенка. Формирование и развитее творческого потенциала учащихся неотделимо от образовательного и воспитательного процесса в целом и невозможно без создания творческой среды в образовательном учреждении, которое способствует развитию познавательных интересов, стимулирует любознательность и создает условия, в которых ребенок развивает свои способности и проявляет одаренность.

Учебно-воспитательный процесс в нашей школе организован с использованием современных педагогических технологий. Мы стремимся использовать каждую возможность для участия одаренных детей в олимпиадах, творческих конкурсах разного уровня. Дополнительное образование позволяет реализовать индивидуальные интересы одаренных детей, которые невозможно реализовать в рамках традиционных учебных предметов. Сотрудничество с ВУЗами позволяет поднять научный уровень образовательной деятельности, познакомить с реальными исследованиями ученых в разных предметных областях.

Главная задача учителя научить ученика учиться. По словам В.А.Сухомлинского «...замечательные, блестящие уроки есть там, где имеется ещё что-то замечательное, кроме уроков, где имеются и успешно применяются самые разнообразные формы развития учащихся вне урока». Основными компонентами субъектного опыта творческой деятельности являются: мотивация творчества, способность творчески мыслить, способность к творческому сотрудничеству, опыт использования полученных знаний в нетрадиционных ситуациях, а также все решенные проблемы и творческие задачи. Приобретение знаний, умений и навыков самостоятельной работы приучает учащихся к творческой работе, развивает творческое мышление, создает предпосылки для их применения в системе профессиональной деятельности, совершенствует способности устного и письменного общения, отдавая предпочтение выражению мнений, эмоций и чувств, а также умению аргументировать. Чем больше разнообразных заданий используется, тем эффективнее результаты. 
Я бы выделила следующие формы работы над развитием творческих способностей учащихся:

- практические занятия,

- использование песен и стихотворений;

- творческие домашние задания;

- ведение языковых портфолио;

- применение компьютерных программ;

- защита рефератов и проектов;

- деловые игры, конференции;

- работа с текстом, диалогом или монологом, построенная необычным способом.

Поэзия и песня могут быть использованы как образец современной аутентичной разговорно-литературной речи для достижения ведущих целей обучения и для развития одаренности.

Метод обучения - более сильное средство, чем содержание обучения. Спросите выпускников школы о том, что им запомнилось больше: чему их обучали или как это происходило? Именно методы творческой деятельности имеют более универсальный общечеловеческий характер, поскольку их можно переносить в различные сферы образования. Такие методы обучения называются эвристическими. (Хуторской Андрей Викторович, доктор педагогических наук, академик Международной педагогической академии, г. Москва). Свое название они получили потому, что результатом их применения всегда является создаваемая учениками образовательная продукция: идея, гипотеза, закономерность, эксперимент, знаковое или текстовое произведение, перевод стихотворений, песен, составленная схема, правило и, конечно, праздник.

Культура праздника на уроках английского языка слагается из культуры слова, культуры движения, культуры музыкального звука, культуры моды, костюма, этикета, обычая, ритуала, словом, из совокупности разных культур.

Известный ученый и педагог Сталь Анатольевич Шмаков особо отмечает, что для детей праздник - всегда выдающееся событие, всегда веселье, торжество, приятное время - провождение и, конечно же, перерыв в однообразии учения. «Может быть, только дети обостренно чувствуют философию каждого праздника, выбранную поколениями?!».

Давно известно: ребенок познает мир, играя. Игра как обязательный компонент праздника побуждает детей к творчеству «взаправду». Особенно актуально это для младшего школьного возраста, где игровая деятельность занимает важное место в познании окружающего мира.

Ребенок везде должен быть самим собой. И на празднике тоже. Потому сочинять и проводить праздники надо по правилам детской игры. А еще праздники любят необычность личного самовыражения, установку на творчество, образность, обрядность, карнавальность, сказочность, костюмированность, сюрпризность, импровизацию, народный колорит, эмоциональность. А главное, за возможность «себя показать и других посмотреть».

Праздник - настоящий, традиционный или новационный явление деятельное. Значимость праздников, особенно детских, невозможно переоценить. Во-первых, это часть духовного наследия народа, его чистейших родников творчества - обрядов, ритуалов, традиций. Во-вторых, праздники - сфера разностороннего творческого сотрудничества детей между собой и детей и взрослых в процессе 
подготовки и проведения праздника. В-третьих, праздничные дни ярчайшие события жизни, некие социальные рубежи, вехи, перспективы, на которые ориентируются, которые ждут. Проведение праздников при изучении английского языка способствует формированию коммуникативных умений и знакомству с важнейшими элементами культурных традиций англоязычных стран.

В нашей школе такими праздниками завершается неделя иностранного языка. На школьной сцене можно увидеть постановки небольших пьес, инсценировки сказок, исполнение песен и стихотворений на английском языке. В начальной школе практикуются «Праздник прощания с английским алфавитом», «Пером водим - переводим», «The Best from the Best», «Времена года» и другие.

Таким образом, урочная и внеурочная, внеклассная деятельность целиком направлена на развитие целеустремленности, настойчивости, привитие детям чувства прекрасного и развитие их творческих и индивидуальных способностей. Проведение уроков и внеклассных мероприятий в оригинальной, нетрадиционной форме направлено не только на развитие основных видов речевой деятельности, но и на формирование ассоциативного мышления, памяти, навыков общения в коллективе, творческой инициативы школьников. Творческий характер заданий, предлагаемых в ходе различных конкурсов, игр и соревнований, способствует лучшему запоминанию и усвоению различных грамматических явлений, расширению лексического запаса, развитию монологической и диалогической речи, а также открывает широкие возможности для индивидуальной работы школьников.

Использование такой коллективной формы работы, как обучение в сотрудничестве, способствует реализации воспитательных целей обучения: школьники становятся субъектами общения, учатся воспринимать, осмысливать и оценивать позицию другого человека, регулировать свое поведение согласно условиям общения. В данном виде деятельности формируется человек культуры - творческая личность.

Огромную роль игры в жизни и развитии ребенка осознавали и отмечали во все времена деятели педагогической науки. «Игра есть высшая ступень детского развития, развития человека этого периода; игра порождает радость, свободу, покой в себе и около себя, мир с миром. Источники всего хорошего лежат в игре и исходят из нее»,- отмечал немецкий педагог Ф. Фребель. «В игре раскрывается перед детьми мир, раскрываются творческие способности личности. Без игры нет, и не может быть полноценного умственного развития», - писал В.А.Сухомлинский. А вот мнение автора экспериментальной методической системы, учителяпрактика современной школы В.Ф.Шаталова: «В играх и в труде, в задорных выдумках и в безудержном веселье во всем многообразии проявляются характеры и способности детей. Таких возможностей, которые раскрывает перед наблюдательным педагогом игра в плане оценки творческих задатков детей, их находчивости, изобретательности, инициативности, не может дать никакой, даже самый лучший в методическом отношении урок».

Нередко наш педагогический интерес к играм, которые верой и правдой служили и призваны служить развитию смекалки и познавательных интересов детей на всех без исключения этапах их возрастного развития, рано угасает. Это ведь не секрет, что те молчуны, из которых на уроке слово не вытянешь, в играх, случается, становятся такими активными, какими мы их в классно-урочных буднях и представить себе не в состоянии. Игра уже одним только своим содержанием переносит ребят в новое измерение, в 
новое психологическое состояние. В игре они обретают не только равноправие, но и реальную возможность стать лидерами, вести за собой других. Их действия, раскрепощенные и уверенные, они начинают выказывать и глубину мышления. Мышления часто смелого, масштабного, нестандартного.

Таким образом, следует всеми доступными средствами создавать игровые ситуации на уроках и, не превращая всего многосложного дела воспитания и обучения в одну только игру, использовать непринужденную обстановку многокрасочных, звонких, брызжущих энергией и смехом игровых элементов.

Я хочу пробудить у моих учеников любовь к знаниям, преклонение перед творчеством и неистовое желание творить самим, веселое и радостное ощущение жизни, готовность и желание помочь себе и другим. Я не хочу подменять их трудные решения своими, пусть они идут по дороге испытаний и получают истинное удовольствие от маленьких своих побед.

Два мира есть у человека:

Один, который нас творил,

Другой, который мы от века

Творим по мере наших сил.

(Н. Заболоцкий).

Каждый учитель стремится сделать свои уроки творческими и занимательными, чтобы желание и интерес школьников, которые только приступили к занятиям иностранным языком, не угасли в последующие годы. Задача учителя - добиться того, чтобы этот интерес был постоянным и устойчивым. А там, где есть интерес, там и успех. 
Библиографический список:

1. Сухомлинский В.А. Избранные педагогические сочинения,1981 г.

2. Фребель, Ф. Воспитание человека; Детский сад; История зарубежной дошкольной педагогики; Хрестоматия /сост. Н.Б. Мчелидзе и др. - М., 1986 $\Gamma$.

3. Хуторской А.В. 55 методов творческого обучения: Методическое пособие. $-\mathrm{M}$.

4. Хуторской А.В. Развитие одарённости школьников: Методика продуктивного обучения: Пособие для учителя. - М.

5. Хуторской А.В. Эвристическое обучение: Теория, методология, практика. Научное издание. - М.: Международная педагогическая академия, 1998. $266 \mathrm{c.}$

6. Шаталов В. Ф., Куда и как исчезли тройки. - М., 1979.

7. Шмаков С. А.Учимся, играя... Издательство: Центр гуманитарной литературы,2003 г.

$$
\text { Интернет - ресурсы: }
$$

1. Методика В.Ф. Шаталова http://msk.treko.ru/show dict 1017

2. Педагоги-новаторы. http://www.altruism.ru/sengine.cgi/13/41/23 